\title{
Haematological Response of African Catfish (Clarias gariepinus Burchell 1822) Fingerlings Exposed to Different Concentrations of Tobacco (Nicotiana tobaccum) Leaf Dust
}

\author{
Safina M. Musa, ${ }^{1}$ Christopher Mulanda Aura, ${ }^{2,3}$ Erick Ochieng Ogello, ${ }^{1}$ Reuben Omondi, \\ Harrison Charo-Karisa, ${ }^{5}$ and Jonathan Mbonge Munguti ${ }^{5}$ \\ ${ }^{1}$ Kegati Aquaculture Research Station, Kenya Marine and Fisheries Research Institute, P.O. Box 3259-40200, Kisii, Kenya \\ ${ }^{2}$ Kenya Marine and Fisheries Research Institute, P.O. Box 81651-80100, Mombasa, Kenya \\ ${ }^{3}$ Laboratory of Marine Bioresource \& Environment Sensing, Hokkaido University, 3-1-1 Minato, Hakodate, Hokkaido 041-8611, Japan \\ ${ }^{4}$ Kenya Marine and Fisheries Research Institute, P.O. Box 1881-40100, Kisumu, Kenya \\ ${ }^{5}$ National Aquaculture Research Development \& Training Center (NARDTC)-Sagana, Kenya Marine and Fisheries Research Institute, \\ P.O. Box 26-10230, Sagana, Kenya
}

Correspondence should be addressed to Safina M. Musa; safeenamusa@yahoo.com

Received 15 July 2013; Accepted 17 August 2013

Academic Editors: I. Krams, T. Miyata, and D. Park

Copyright (C) 2013 Safina M. Musa et al. This is an open access article distributed under the Creative Commons Attribution License, which permits unrestricted use, distribution, and reproduction in any medium, provided the original work is properly cited.

The present study set out to investigate the haematological effects of tobacco leaf dust on African catfish, Clarias gariepinus, fingerlings, with a mean weight of $3.01 \pm 1.25 \mathrm{~g}$ using "static renewal bioassay system" during a 120-hour bioassay exposure period. Water quality parameters such as $\mathrm{pH}$ and dissolved oxygen significantly decreased while total alkalinity and conductivity increased significantly in the exposed media, compared to the control test. Leucocytes counts increased significantly while erythrocytes counts decreased significantly with increasing concentration of tobacco dust. Packed cell volume significantly reduced with increase in the concentration of tobacco dust. Haematological examination showed that there was destruction of the erythrocytes production, and the concentration of haemoglobin was much lower in the exposed fish compared to the control depicting an anaemic condition. The results could provide baseline information for the safe limits of using tobacco leaf dust in fish ponds; hence $1.56 \mathrm{~g} \mathrm{~L}^{-1}$ concentration of tobacco leaf dust was recommended for pond preparation for Clarias gariepinus fingerling stocking. For better survival rates, the fish should only be introduced in the pond after three days of tobacco application.

\section{Introduction}

African catfish (Clarias gariepinus) is one of the most important fish species currently being cultured both inside and outside its natural range of tropical and subtropical environments $[1,2]$. Positive attributes such as resistance to diseases, high fecundity, and ease of larval production in captivity make it of commercial importance in aquaculture [3-5]. However, the main constraint facing the culture of $C$. gariepinus is the low survival during the larval and fingerling stages [6] leading to insufficient amounts of quality catfish seed. High mortality rates occur among larval stages of catfish, some of which are attributed to infectious diseases caused by parasites [7]. Parasitic pathogens infecting cultured fish are well known to cause mortality and significant losses both in culture and capture fisheries [8,9]. It is therefore apparent that management protocols that limit mortality and enhance fingerling growth should be clearly described to ensure improved survival and sufficient supply of catfish fingerlings.

Fish farmers often use tobacco leaf in controlling unwanted organisms and pests $[10,11]$. The attraction of tobacco leaf dust as a biocide according to Aleem [12] is because of its inexpensiveness, local availability, and easy degradability. According to Ogello et al. [13], tobacco concentrations of $1.75 \mathrm{~g} \mathrm{~L}^{-1}$ and $2.0 \mathrm{~g} \mathrm{~L}^{-1}$ had high hazard ratios and low survival rates and were the most effective in the eradication of $M$. tuberculatus and are the recommended 
dose for preparing ponds for stocking. In Taiwan, for example, tobacco waste dust is applied at 1 ton/acre as a pesticide and fertilizer in fish ponds [14]. Notwithstanding, tobacco leaf dust has been used in Nigeria as an effective insecticide to predators and pest in water (pond) since it is completely biodegradable [12]. The active ingredient of tobacco is nicotine which is lipophilic in nature with high solubility in membrane lipid and fast influx into cells [15]. It is easily absorbed in body and can penetrate the epithelial and blood cells [16]. Despite the effective use of tobacco leaf dust, it should not be used directly in water bodies unless their toxicity and sublethal long-term effect on target and nontarget animals are known.

Several authors have documented the effect of tobacco dust on blood of fish $[17,18]$. However, the sublethal concentration and time at which $50 \%$ of the fish survive $\left(\mathrm{LC}_{50}, \mathrm{LT}_{50}\right)$ in the literature differ significantly. For example, whereas Omoniyi et al. [17] reported $\mathrm{LC}_{50}$ at $626.0 \mathrm{mg} \mathrm{L}^{-1}$ after 48 hours, Agbon et al. [18] found $\mathrm{LC}_{50}$ at $109.6 \mathrm{mg} \mathrm{L}^{-1}$ after 72 hours. In addition, there seems to be no general agreement on the toxicological effects of tobacco leaf dust on various fish species. For example, Omoniyi et al. [17] reported that sublethal leaf exposure showed progressive decrease in fish weight while haematological indices indicated that the $C$. gariepinus became anaemic. Similarly, Agbon et al. [18] found out that there was no significant effect on blood parameters of C. gariepinus. Despite the effective use of tobacco leaf dust, its ecotoxic properties are of interest to ecotoxicologists. As a rule, pesticides/piscicides of plant origin should not be used directly in freshwater bodies unless their toxicity and sublethal long-term effect on nontarget animals, sharing the habitat with the target animals, have been determined [10]. The knowledge of sublethal effects of tobacco is important to delineate the status of fish health and to provide a future understanding of ecological impacts [19]. The aim of this study was to ascertain sublethal concentrations and haematological changes with time in the African catfish $C$. gariepinus exposed to tobacco ( $N$. tobaccum) for a period of 5 days. This would in the long run provide an optimal dosage of tobacco N. tobaccum for improved survival of catfish.

\section{Materials and Methods}

The study was conducted in a laboratory at Kenya Marine and Fisheries Research Institute at Kegati Aquaculture Research Station, Kisii, Kenya $\left(00^{\circ} 42^{\prime \prime} S ; 034^{\circ} 47^{\prime \prime} \mathrm{E}\right)$. Three thousand seven hundred fifty catfish fingerlings of the same cohort (with a mean weight of $3.01 \pm 1.25 \mathrm{~g}$ ) were obtained from the Department of Fisheries in Kisii Fish Farm. They were acclimatized in a glass tank for 24 hours in the lab and later transferred to the experimental glass aquaria. The fingerlings were stocked at a density of 250 fish in $50 \mathrm{~L}^{-1}$ of water. The tobacco leaves were sun-dried for 7 days and milled into powder, sieved, and stored in a sealed plastic paper bag. The concentrations of tobacco used were calculated as $50 \%$ $120 \mathrm{~h} \mathrm{LC}_{50}\left(120 \mathrm{~h} \mathrm{LC}_{50}\right.$ of tobacco leaf dust on C. gariepinus obtained from preliminary investigation).
Finely ground powder of dry tobacco dust was used to make solutions of concentrations 0.00 (control), 1.25, $1.50,1.75$, and $2.00 \mathrm{~g} \mathrm{~L}^{-1}$ using borehole water and poured into $100 \mathrm{~L}$ glass aquaria half-filled to maintain fifty liters of water throughout the exposure period. Each concentration was in triplicate. The doses were selected based on the experiment that had been previously conducted at the station using tobacco for parasite control in fish was pond [13]. The objectives of this renewal study are to extend the study on efficacy of tobacco waste and conduct experiments to determine the sublethal concentration that is safe to non target organism such as fish. In order to monitor the toxicant strength, level of dissolved oxygen, the effects of evaporation, and ammonia concentration and in order to reduce stress during experimentation, the test media were replaced by $50 \%$ prepared concentrations of the same quantity after removing its equivalent along with defecation once every day to maintain the requisite level and potency of the concentration. The exposure period lasted for 120 hours during which the selected water quality parameters that included temperature, dissolved oxygen, conductivity, alkalinity, and $\mathrm{pH}$ were monitored daily following the methods described in APHA [20]. Behaviour and mortality rates of the test fish were monitored and recorded hourly.

The fish were fed with isonitrogenous (30\%) diet formulated from shrimp meal (Caridina nilotica), cottonseed meal (CSM), and wheat bran (WB) ad libitum, twice daily during the entire experimental period. After 120 hours, 15 fishes were sacrificed in each treatment and analyzed for the haematological examination. Blood was obtained from randomly selected fish for treatments and control after the 120 hours, using $2.0 \mathrm{~mL}$ plastic syringe, as described by KoriSiakpere [21]. The fish were then placed belly upwards and blood samples obtained from the caudal circulation with the aid of heparinised $2 \mathrm{~cm}^{3}$ disposable plastic syringes and a 21gauge disposable hypodermic needle. A plastic syringe was used to obtain fish blood because contact with glass results in decreased coagulation time [22]. The site chosen for puncture (about 3-4 cm from the genital opening) was wiped dry with tissue paper to avoid contamination with mucus. The blood was transferred into a lithium heparin anticoagulant tube at room temperature for 30-40 minutes [23] and stored in the refrigerator until analyses.

The colorimetric method was used to determine the total protein (biuret reaction) and albumin levels. Red blood cell (RBC), total white blood cell (WBC), and platelet counts were done using the Neubauer haemocytometer. The haematocrit or packed cell volume (PCV) and haemoglobin $(\mathrm{Hb})$ concentration values were determined by the microhaematocrit capillary tube and cyanomethaemoglobin methods [24], respectively. Percentage of RBC and WBC was determined by counting 1,500 cells. The WBC percentage was multiplied by the RBC count from the haemocytometer to determine the WBC absolute count. For the differential count, WBC were counted until $200 \mathrm{WBC}$ were enumerated on blood smears, and the percentage of each WBC type was multiplied by the total WBC count to obtain absolute differential cell counts. This method of manually determining the total WBC and differential count has been recommended for avian [25] and 
TABLE 1: Mean values $( \pm$ SE) of water quality parameters for the different concentrations of tobacco $(N$. tobaccum) leaf dust during the 120 -hour exposure period.

\begin{tabular}{|c|c|c|c|c|c|c|}
\hline \multirow{2}{*}{ Parameter } & \multicolumn{6}{|c|}{ Treatment $\left(\mathrm{mg} \mathrm{L}^{-1}\right)$} \\
\hline & 0.00 & 1.25 & 1.5 & 1.75 & 2.00 & 2.25 \\
\hline Temperature $\left({ }^{\circ} \mathrm{C}\right)$ & $22.3 \pm 0.0^{\mathrm{a}}$ & $22.4 \pm 0.2^{\mathrm{a}}$ & $22.4 \pm 0.01^{\mathrm{a}}$ & $22.4 \pm 0.1^{\mathrm{a}}$ & $22.4 \pm 0.2^{\mathrm{a}}$ & $22.4 \pm 0.1^{\mathrm{a}}$ \\
\hline Dissolved oxygen $\left(\mathrm{mg} \mathrm{L}^{-1}\right)$ & $8.7 \pm 0.1^{\mathrm{a}}$ & $8.1 \pm 0.3^{b}$ & $6.9 \pm 0.3^{c}$ & $5.5 \pm 1.1^{\mathrm{d}}$ & $5.1 \pm 0.0^{\mathrm{e}}$ & $4.3 \pm 2.2^{\mathrm{f}}$ \\
\hline $\mathrm{pH}$ & $6.8 \pm 0.0^{\mathrm{a}}$ & $6.5 \pm 0.1^{b}$ & $6.2 \pm 0.0^{c}$ & $5.8 \pm 0.2^{\mathrm{d}}$ & $5.4 \pm 0.1^{\mathrm{e}}$ & $5.0 \pm 0.0^{\mathrm{f}}$ \\
\hline Conductivity $\left(\mu \mathrm{S} \mathrm{cm}^{-1}\right)$ & $102.8 \pm 1.2^{\mathrm{a}}$ & $137.2 \pm 2.4^{\mathrm{b}}$ & $143.1 \pm 2.4^{\mathrm{c}}$ & $148.6 \pm 2.3^{\mathrm{d}}$ & $152.4 \pm 1.4^{\mathrm{e}}$ & $158.3 \pm 1.2^{\mathrm{f}}$ \\
\hline Total alkalinity $\left(\mathrm{mg} \mathrm{L}^{-1}\right)$ & $73.8 \pm 0.0^{\mathrm{a}}$ & $91.1 \pm 0.4^{\mathrm{b}}$ & $102.5 \pm 2.1^{\mathrm{c}}$ & $112.5 \pm 1.2^{\mathrm{d}}$ & $129.8 \pm 0.7^{\mathrm{e}}$ & $137.9 \pm 1.4^{\mathrm{f}}$ \\
\hline
\end{tabular}

Values in the same row with the same superscripts are not significantly different $(P>0.05)$. SE: standard error of the mean.

TABLE 2: Mean values $( \pm \mathrm{SE})$ of blood parameters of $C$. gariepinus exposed to tobacco leaf dust concentrations for 120 hours.

\begin{tabular}{lcccccc}
\hline \multirow{2}{*}{ Treatments $\left(\mathrm{mg} \mathrm{L}^{-1}\right)$} & \multicolumn{5}{c}{ Haematological parameters } \\
& PCV $(\%)$ & RBC $\left(\mathrm{mm}^{3}\right)$ & WBC $\left(\mathrm{mm}^{3}\right)$ & $\mathrm{HB}\left(\mathrm{g} \mathrm{dL}^{-1}\right)$ & Total protein $\left(\mathrm{mg} \mathrm{dL}^{-1}\right)$ & $\mathrm{Albumin}\left(\mathrm{mg} \mathrm{dL}^{-1}\right)$ \\
\hline 0 & $18.00 \pm 1.22$ & $1.71 \pm 0.26$ & $4.08 \pm 0.00$ & $7.03 \pm 2.64$ & $6.14 \pm 0.13$ & $3.48 \pm 0.22$ \\
1.25 & $16.00 \pm 1.01$ & $1.67 \pm 0.65$ & $5.84 \pm 0.10$ & $5.12 \pm 0.32$ & $5.91 \pm 0.19$ & $3.01 \pm 1.13$ \\
1.5 & $10.8 \pm 0.66$ & $1.33 \pm 1.05$ & $6.14 \pm 0.12$ & $4.23 \pm 1.01$ & $4.44 \pm 0.23$ & $2.74 \pm 0.13$ \\
1.75 & $10.1 \pm 0.86$ & $1.30 \pm 0.22$ & $6.20 \pm 0.14$ & $3.30 \pm 0.42$ & $3.84 \pm 0.21$ & $2.39 \pm 2.34$ \\
2 & $8.12 \pm 1.38$ & $1.22 \pm 0.54$ & $6.25 \pm 0.88$ & $1.34 \pm 0.41$ & $3.24 \pm 0.21$ & $2.11 \pm 1.23$ \\
2.25 & $8.01 \pm 1.83$ & $1.21 \pm 1.04$ & $6.28 \pm 0.84$ & $0.82 \pm 0.13$ & $2.24 \pm 0.18$ & $1.89 \pm 1.26$ \\
\hline
\end{tabular}

PCV: packed red cell volume; RBC: red blood cell; WBC: white blood cell; HB: haemoglobin.

fish [26] blood, because nucleated RBC prevents accurate enumeration using automated analysis [27].

Data were recorded in the Microsoft excel sheets and analyzed with STATISTICA version 8.0 (Inc. 2010) for means and standard errors. Since there was no significant variation in the replica of the data employed, the pooled data values for the mean values of the treatment were subjected to statistical analysis using one-way analysis of variance (ANOVA) to test the level of significance between the various concentrations of tobacco ( $N$. tobaccum) leaf dust. The percentage of survival variations among aquaria was compared using multiple comparisons with a Bonferroni-corrected alpha (significance considered at $P<0.008$ ) to minimize the possibility of type I statistical error. The median lethal concentration was determined following Fry [28]. Probit model was employed as a survival analysis model to show the sublethal concentration $\mathrm{LC}_{50}$ for $C$. gariepinus exposed to tobacco leaf. The data presented in this model had two parameters, one relating to survival (probit) and the other to tobacco leaf dust concentration (as $\log x$-axis). The model assumed that for a given initial proportion, the hazards at different concentrations of tobacco waste were proportional to each other.

\section{Results}

Mean values of water quality parameters for the different concentrations of tobacco leaf dust and control media to which the test fish C. gariepinus were exposed over the 120hour exposure period are presented in Table 1 . Mean values of the water temperature were not significantly $(P>0.05)$ affected by the concentrations of tobacco. On the other hand, $\mathrm{pH}$ and dissolved oxygen significantly $(P<0.05)$ decreased as the concentrations of tobacco leaf dust increased. However, the values of total alkalinity and conductivity in the exposed media significantly $(P<0.05)$ increased as the concentrations of tobacco leaf dust increased, compared to the control test.

The mean values of haematological analysis of the blood of C. gariepinus are presented in Table 2. The results indicated that erythrocyte volume reduced from mean value of 1.71 to $1.21 \mathrm{~mm}^{3}$ with an increase in the concentration of tobacco leaf dust. The decrease in these values was observed to be both a factor of time and the concentration of tobacco. Haemoglobin values reduced from 7.03 to $0.82 \mathrm{~g} \mathrm{dL}^{-1}$ with increase in the concentration from 0.0 to $2.5 \mathrm{~g} \mathrm{~L}^{-1}$. It was observed that leucocytes counts increased significantly ( $\mathrm{df}=$ $17 ; F=63.42 ; P=0.03$ ) while erythrocytes and packed cell volume counts reduced significantly $(P<0.05)$ with increasing concentration of tobacco dust. In addition, total protein and albumin values significantly decreased $(\mathrm{df}=17$; $F=51.71 ; P=0.04)$ with increasing concentration of tobacco dust.

For the freshly prepared tobacco solutions, C. gariepinus showed hyperventilation, erratic swimming, and loss of reflex and this increased with increasing concentrations of tobacco leaf dust but decreased in 2-day, 3-day, 4-day, and 5-day old solutions. Multiple disorders of hyperventilation, erratic swimming, and loss of reflex rates for the treatment above $1.5 \mathrm{~g} \mathrm{~L}^{-1}$ were the highest and the percentage of survival beyond $1.5 \mathrm{~g} \mathrm{~L}^{-1}$ concentration differed significantly (Bonferroni-corrected probability, all $P<0.05$ ) with a strong significant negative relationship $\left(r^{2}=0.91\right)$ between the survival of C. gariepinus exposed to various concentrations of tobacco waste solution during the study period (Figure 1). The $\mathrm{LC}_{50}$ of tobacco leaf extract was $1.56 \mathrm{~g} \mathrm{~L}^{-1}$ with $\mathrm{LT}_{50}$ of $\approx 72 \mathrm{~h}$ (Figure 2). 


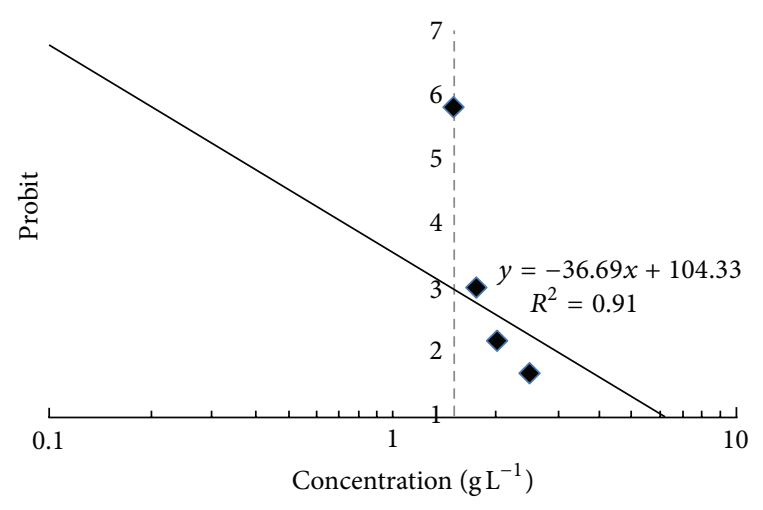

Figure 1: Probit model showing the relationship between survival rates of C. gariepinus exposed to various concentrations of tobacco waste solution during the study period.

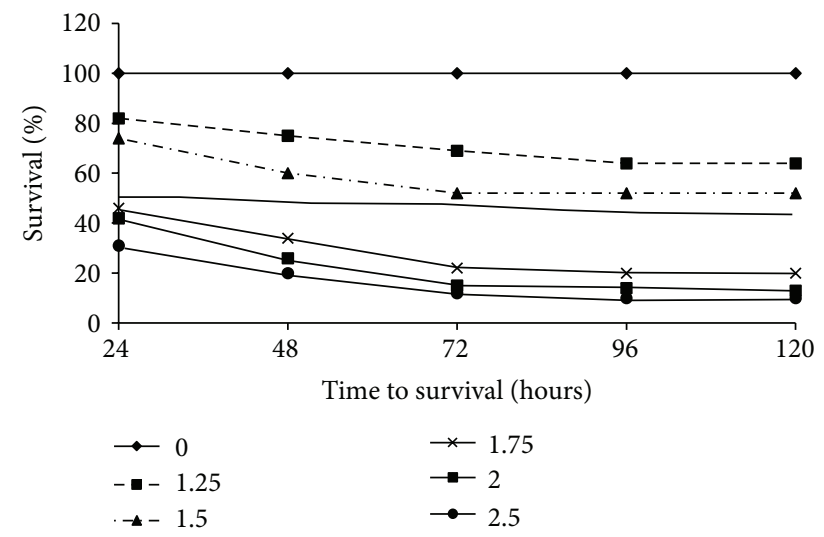

FIgURE 2: The cumulative survival rates (\%) of C. gariepinus exposed to various concentrations of tobacco waste solution during the study period.

\section{Discussions}

Based on the present findings, changes in the water quality parameters showed that the tobacco leaf dust concentrations significantly affected the water quality. According to Omoniyi et al. [17], sublethal effects of tobacco leaf dust on the haematological parameters of the C. gariepinus revealed increased and decreased insignificant difference in the monitored water quality parameters. The variation in the reported result of monitored parameters could be associated with the exposure period and the level of tobacco leaf dust concentrations. The value of $\mathrm{pH}$ in the highest concentration of tobacco leaf dust was found to be lower than the recommended value for fresh water fish $[29,30]$, probably indicating development of acidic condition as the toxicant strength increased. Similar findings were reported by Omoniyi et al. [17] who reported the acidic condition in the water of C. gariepinus exposed to tobacco leaf dust. The decline in $\mathrm{pH}$ with time could be due to the production of acidic metabolites [31]. The acidic condition of the water has resulted in the decrease in the level of dissolved oxygen, with a corresponding increase in the values of total alkalinity and conductivity.
Houston et al. [32] reported changes in the blood parameters of fresh water fish exposed to various handling procedures before experiment and the effect of stress on the fish. The disrupted haematological parameters observed in the present experiment concurred with the findings of Akinbulumo [33] who reported that the fish showed a toxic reaction to Derris elliptica root powder by surfacing jaws and becoming stupefied. Reduction in oxygen level in the present study is similar to Lloyd [34] who reported that the toxicity of several poisons on the rainbow trout increased inversely to the oxygen concentrations of water. A number of poisons become more toxic at low oxygen concentrations because of an increased respiratory rate, thus increasing the amount of poison to which the animal is exposed [11].

In the light of the present study, it is obvious that the exposure of C. gariepinus to tobacco leaf dust caused a significant decrease in the concentration of haemoglobin. The decrease in haematocrit, an anaemic response, has been reported in C. gariepinus exposed to malachite green [35]. The effect of sublethal concentration of formothion has been reported by Singh and Srivastava [36] with a significant decrease in haematocrit and haemoglobin concentration in Heteropneustes fossil, and a decrease in haemoglobin has been reported by Santhakumar et al. [37] in Anabas testudineus. The significant reduction in the values of the haemoglobin as the concentration of the toxicant, tobacco leaf dust, increases is an indication of severe anaemia in C. gariepinus. The anaemic response could be as a result of the destruction or inhibition of erythrocyte production $[18,38]$ or haemodilution as reported by Sampath et al. [39].

Consequently, white blood cell values increased with increasing concentration of tobacco leaf dust. The significant increase in the values of white blood cell as the concentration of tobacco increased could be attributed to the increase in leucocytes synthesis as a defense mechanism against the destruction of erythrocytes. Lymphocytes are the most numerous cells comprising the leucocytes, which function in the production of antibodies and chemical substances serving as a defence against infection [40]. In addition, the increase in values of leucocytes could probably indicate that the fish were less stressed by the increasing concentrations of tobacco dust because leucocyte profiles are altered by stress and can be directly related to stress hormone levels [41].

Packed red cell volume values reduced with increasing tobacco waste, and this is traceable to different fishes having different blood parameters unlike human blood that is constant [42]. The present study corroborates that of Mason [43] who reported similar observation when subjecting $C$. gariepinus to a sublethal concentration of formalin. The result from statistical analysis shows that there is reduction in some of the blood parameters, which could be an indication of anemia which is a condition characterized by a deficiency of haemoglobin, packed cell volume, and erythrocytes. Haematology studies in teleosts have indicated that haematocrit values might be useful as a general indicator of fish health, since fish given iron deficient diets, or those exhibiting anaemia, all possess reduced haematocrit (PCV) values [44].

The decrease in total protein reported in this study was supported by the study of Das and Mukherjee [45] on 
Labeo rohita exposed to sublethal concentrations of cypermethrin. Tiwari and Singh [46] reported a decrease in serum total protein in snake head fish (Channa punctatus) exposed to sublethal concentrations of lattices of Euphorbia royleana. Reeta et al. [47] reported inhibition in the total serum protein of an air breathing fish Heteropneustes fossilis after exposure to different pesticides (DDT, YBHC, and Malathion). Ravichandran et al. [48] reported depletion of protein due to proteolysis after exposing Oreochromis mossambicus to nominal concentrations of phenol. The decrease in protein content might also be attributed to the destruction or necrosis of the cells and consequent impairment in protein synthesis machinery [49].

The decrease in albumin values reported in the present study was supported by the study of Jee et al. [50] on Korean rock fish (Sebastes schlegeli) exposed to cypermethrin. The decrease in the value of albumin may impede its function of transportation. The significant decrease in albumin may have resulted from the inhibitory effect of the plant dust on protein hydrolytic activity due to elevation of protease activity which corresponds with the values of total protein [50].

Exposure of C. gariepinus fingerlings to tobacco leaf dust solution clearly disrupted haematological parameters in the present study. Haematocrit, haemoglobin values, erythrocyte and leucocyte counts, and total protein and albumin of the fish exposed to different concentrations of tobacco leaf dust revealed significant haematological alterations and changes (Table 2). Studies have shown that when the water quality is affected by toxicants, many physiological changes will be reflected in the values of one or more of the haematological parameters [51]. Thus, water quality is one of the major factors that could be responsible for individual variations in fish haematology since they live in close association with their environment and are sensitive to the slightest fluctuation that may occur within their internal milieu [52].

We observed an increase in erratic swimming and loss of reflex for the test fish as concentrations of tobacco dust were increased. According to Aleem [12], this could probably be due to irritation from increased nicotine content. Nicotine can bind onto acetylcholine receptors in the nervous system, thus causing the excitation and restlessness [53]. This behaviour was more pronounced in freshly prepared solutions as compared to 1-day, 2-day, 3-day, 4-day, and 5day-old solutions, an indication that the test fish were less irritated by the older solution compared with freshly prepared solution. Aleem [12] indicated that older solutions lose an appreciable amount of nicotine toxicity.

The results of the present study indicated that a $120 \mathrm{~h}$ $\mathrm{LC}_{50}$ was at $1.56 \mathrm{~g} \mathrm{~L}^{-1}$ of tobacco leaf extract. This was beyond lethal concentrations reported to be effective in controlling parasites in fish ponds [54] and hence could be used safely to prepare ponds for stocking. However, for better survival, fingerlings should only be introduced after 72 hours of pond treatment because their toxic effect is reversible within three days after application and it is environmentally safe. Compared to other synthetic pesticides used in fish farming, such as carbamates and organophosphates, tobacco based products are certainly less toxic to fish [55]. The acute toxicity of tobacco leaf dust on Oreochromis niloticus has been studied [18] and reported to have $48 \mathrm{~h} \mathrm{LC}_{50}$ at $109.6 \mathrm{mg} \mathrm{L}^{-1}$. This value is far lower than the estimated sublethal concentration in this study (Figure 1), thus indicating that C. gariepinus is probably more resistant to tobacco toxicity. Further studies are therefore recommended to investigate the effect of tobacco waste on other tropical fish, for example, tilapia and Labeo (Labeo victorianus).

\section{Conflict of Interests}

The authors state that there is no financial relation with the mentioned enterprise therein which might lead to conflict of interests among themselves or between them and the institutions therein. In addition, the authors are purely trained researchers with the information herein only meant for research purposes and therefore they account for their output based on research and information dissemination. In addition, there is no conflict of interests among all the authors, financier, and the organization herein that could inappropriately influence, or be perceived to influence, their work. Notably, the work herein has not been previously published or submitted to another journal, but only to this journal.

\section{Acknowledgments}

Kenya Marine and Fisheries Research Institute (KMFRI) provided the necessary funds and materials required during the study.

\section{References}

[1] M. A. Adewolu, C. A. Adeniji, and A. B. Adejobi, "Feed utilization, growth and survival of Clarias gariepinus (Burchell 1822) fingerlings cultured under different photoperiods," Aquaculture, vol. 283, no. 1-4, pp. 64-67, 2008.

[2] V. Chepkirui-Boit, C. C. Ngugi, J. Bowman et al., "Growth performance, survival, feed utilization and nutrient utilization of African catfish (Clarias gariepinus) larvae co-fed Artemia and a micro-diet containing freshwater atyid shrimp (Caridina nilotica) during weaning," Aquaculture Nutrition, vol. 17, no. 2, pp. e82-e89, 2011.

[3] G. S. Haylor, "Controlled hatchery production of Clarias gariepinus (Burchell 1822) : growth and survival of fry at high stocking density," Aquaculture \& Fisheries Management, vol. 22, no. 4, pp. 405-422, 1991.

[4] H. Hogendoorn, "Controlled propagation of the African catfish, Clarias lazera (C. \& V.)-III. Feeding and growth of fry (Artemia)," Aquaculture, vol. 21, no. 3, pp. 233-241, 1980.

[5] P. Kestemont, I. Toko, E. D. Fiogbe, and B. Koukpode, "Rearing of African catfish (Clarias gariepinus) and vundu catfish (Heterobranchus longifilis) in traditional fish ponds (whedos): effect of stocking density on growth, production and body composition," Aquaculture, vol. 262, no. 1, pp. 65-72, 2007.

[6] G. J. de Graaf and H. Janssen, "Artificial reproduction and pond rearing of the African catfish, Clarias gariepinus in sub-Saharan Africa. A handbook," Tech. Rep. 362, FAO Fisheries, Rome, Italy, 1996. 
[7] I. Bricknell and R. A. Dalmo, "The use of immunostimulants in fish larval aquaculture," Fish and Shellfish Immunology, vol. 19, no. 5, pp. 457-472, 2005.

[8] M. J. Costello, "The global economic cost of sea lice to the salmonid farming industry," Journal of Fish Diseases, vol. 32, no. 1, pp. 115-118, 2009.

[9] P. T. K. Woo, "Fish diseases and disorders," in Protozoan and Metazoan Infections, P. T. K. Woo, Ed., vol. 1, pp. 46-114, CABI, Oxfordshire, UK, 2nd edition, 2006.

[10] S. K. Konar, "Nicotine as a fish poison," The Progressive Fish Culturist, vol. 32, pp. 103-104, 1970.

[11] J. G. Tobor, "The Fishing Industry in Nigeria: Status and potential for self sufficiency in fishing production," Tech. Rep. 54, Nigeria Institute for Oceanography Research (NIOMR), Lagos, Nigeria, 1990.

[12] S. O. Aleem, "An assessment of tobacco waste for control of the gastropod Tympanotonus fuscatus (Linnaeus) in brackishwater fish ponds," Aquaculture, vol. 73, no. 1-4, pp. 19-25, 1988.

[13] E. O. Ogello, R. Omondi, M. A. Opiyo, H. Charo-Karisa, J. Munguti, and C. M. Aura, "Survival and avoidance response of the freshwater gastropod Melanoides tuberculatus (Muller) to different concentrations of tobacco waste," Aquaculture Research, vol. 43, pp. 1571-1576, 2012.

[14] V. G. Jhingran, Fish and Fisheries in India, Hindustan Publishing Corporation, New Delhi, India, 1975.

[15] K. A. Hassal, The Chemistry of Pesticides, Macmillan press, London, UK, 1982.

[16] J. A. Dani, D. Ji, and F.-M. Zhou, "Synaptic plasticity and nicotine addiction," Neuron, vol. 31, no. 3, pp. 349-352, 2001.

[17] I. I. Omoniyi, A. O. Agbon, and S. A. Sodunke, "Effects of lethal and sublethal concentrations of tobacco (Nicotiana tobaccum) leaf dust extract on weight and haematological changes in Clarias gariepinus (Burchell)," Journal of Applied Sciences and Environmental Management, vol. 6, pp. 37-41, 2002.

[18] A. O. Agbon, I. I. Omoniyi, and A. A. Teko, "Acute toxicity of tobacco (Nicotiana tobaccum) leaf dust on Oreochromis niloticus and haematological changes resulting from sublethal exposure," Journal of Aquatic Science, vol. 17, pp. 5-8, 2002.

[19] V. Radhaiah, M. Girija, and K. J. Rao, "Changes in selected biochemical parameters in the kidney and blood of the fish, Tilapia mossambica (Peters), exposed to heptachlor," Bulletin of Environmental Contamination and Toxicology, vol. 39, no. 6, pp. 1006-1011, 1987.

[20] APHA, Standard Methods for Examination of Water and Waste Water, America Public Health Association, Washington, DC, USA, 1998.

[21] O. Kori-Siakpere, "Petroleum induced alterations in the haematological parameters of Clarias gariepinus," Nigerian Journal of Science and Environmental, vol. 1, pp. 87-92, 1998.

[22] G. G. Smith, W. M. Lewis, and H. M. Kaplan, "A comparative morphologic and physiologic study of fish blood," The Progressive Fish-Culturist, vol. 14, pp. 168-197, 1952.

[23] G. P. Mahoba, Studies on Indian Cichlids [Ph.D. thesis], University of Science and Technology, Cochin, India, 1987.

[24] E. F. Hesser, "Methods of routine fish hematology," Progressive Fish Culturist, vol. 22, pp. 164-171, 1960.

[25] J. G. Zinkl, "Avian hematology," in Schalm'S Veterinary Hematology, N. C. Jain, Ed., pp. 256-260, Pai hea and Febiger, Philadelphia, Pa, USA, 1986.

[26] M. K. Stoskopf, Clinical Pathology in Fish Medicine, W.B. Saunders Company, Hartcourt Brace Jovanourah Inc., 1993.
[27] P. A. Huffman, M. R. Arkoosh, and E. Casillas, "Characteristics of peripheral blood cells from rainbow trout evaluated by particle counter, image analysis, and hemocytometric techniques," Journal of Aquatic Animal Health, vol. 9, no. 4, pp. 239-248, 1997.

[28] F. E. J. Fry, "The effects of environmental factors on the physiology of fish," in Fish Physiology, W. S. Hoar and D. J. Randall, Eds., vol. 6, pp. 1-98, Academic Press, London, UK, 1971.

[29] E. J. Noga, Fish Disease: Diagnosis and Treatment Mosby Yearbook, Weslin Industrial Drive Inc, St. Louis, Miss, USA, 1996.

[30] R. Richards, “Diseases of aquarium fish-4: Treatment," Veterinary Record, vol. 101, no. 9, pp. 166-167, 1977.

[31] U. Delyan, H. Harder, and T. H. Hopner, "Hydrocarbon biodegradation in sediments and soils. A systematic examination of physical and chemical conditions Part II. pH values," Wissenschaft Science \& Technik, vol. 43, pp. 337-342, 1990.

[32] A. M. Houston, J. A. Madden, R. J. Wood, and H. M. Miles, "Variation in the blood and tissue chemistry of Brook trout, Salvelinus fontinalis subsequent," Journal of the Fisheries Research Board of Canada, vol. 28, pp. 635-642, 1971.

[33] M. O. Akinbulumo, "Derris elliptica as anaesthetic agent on Nile Tilapia, Oreochromis niloticus (Linne, 1758)," Applied Tropical Agriculture, vol. 10, pp. 24-27, 2005.

[34] R. Lloyd, "Effect of dissolved oxygen concentration on the toxicity of several poison," Biology, vol. 38, pp. 447-455, 1961.

[35] S. O. Musa and E. Omoregie, "Haematological changes in the mudfish, Clarias garipinus (Burchell) exposed to malachite green," Journal of Aquatic Sciences, vol. 14, pp. 37-42, 1999.

[36] N. N. Singh and A. K. Srivastava, "Hematology and plasma chemistry reference Intervals for cultured tilapia (Oreochomis hybrid)," Journal of Eco Toxicology and Environmental Monitoring, vol. 4, pp. 137-140, 1999.

[37] M. Santhakumar, M. Balaji, and K. Ramadu, "Hematological response to non-familiar diets. A study of the African mud catfish Clarias gariepinus," Bulletin of Environmental Contamination and Toxicology, vol. 63, pp. 379-384, 1992.

[38] M. M. Wintrobe, Clinical Haematology, H. Klimpton, London, UK, 1978.

[39] K. Sampath, S. Velamnical, I. J. Kennedy, and R. James, "Haematological changes and their recovery in Oreochromis mossambicus as a function of exposure period and sub-lethal level of Ekalus," Acta Hydrobiologica, vol. 35, pp. 73-83, 1993.

[40] G. A. Wedemeyer and J. Wood, Stress a Predisposing Factor in Fish Disease, U.S.Fish/Wildlife Service fish diseases leaflet, 1974.

[41] F. S. Dhabhar, A. H. Miller, B. S. McEwen, and R. L. Spencer, "Stress induced changes in blood leukocyte distribution-role of adrenal steroid hormones," Journal of Immunology, vol. 157, no. 4, pp. 1638-1644, 1996.

[42] F. J. Baker and R. E. Silverton, Introduction to Medical Lab Tech, Butterworth Scientific, London, UK, 5th edition, 1982.

[43] C. F. Mason, Biology of Freshwater Pollution, Longman, London , UK, 3rd edition, 1998.

[44] D. M. Gatlin III and R. P. Wilson, "Dietary copper requirement of fingerling channel catfish," Aquaculture, vol. 54, no. 4, pp. 277-285, 1986.

[45] B. K. Das and S. C. Mukherjee, "Toxicity of cypermethrin in Labeo rohita fingerlings: Biochemical, enzymatic and haematological consequences," Comparative Biochemistry and Physiology C, vol. 134, no. 1, pp. 109-121, 2003. 
[46] S. Tiwari and A. Singh, "Metabolic changes in the Snake head fish Channa punctatus due to lattices of Euphorbia royleana," Asian Fisheries Science, vol. 16, pp. 147-155, 2003.

[47] P. Reeta, S. Bhargava, and D. K. Saraf, "Toxic effects of some biocides on total serum protein in Heteropneustes fossilis," Indian Journal of Environment and Toxicology, vol. 3, pp. 5-6, 1993.

[48] S. Ravichandran, K. Midhunashanthi, and N. Indira, "Impact of phenol on protein metabolism in the freshwater fish Oreochromis mossambicus," Journal of Ecotoxicology and Environmental Management, vol. 4, pp. 33-37, 1994.

[49] S. P. Bradbury, D. M. Symonik, J. R. Coats, and G. J. Atchison, "Toxicity of fenvalerate and its constituent isomers to the fathead minnow, Pimephales promelas, and bluegill, Lepomis macrochirus," Bulletin of Environmental Contamination and Toxicology, vol. 38, no. 5, pp. 727-735, 1987.

[50] J.-H. Jee, F. Masroor, and J.-C. Kang, "Responses of cypermethrin-induced stress in haematological parameters of Korean rockfish, Sebastes schlegeli (Hilgendorf)," Aquaculture Research, vol. 36, no. 9, pp. 898-905, 2005.

[51] J. H. J. Van Vuren, "The effects of toxicants on the haematology of Labeo umbratus (Teleostei: Cyprinidae)," Comparative Biochemistry and Physiology C, vol. 83, no. 1, pp. 155-159, 1986.

[52] E. Cassilas and L. S. Smith, "Rubber seed oil versus palm oil in broiler chicken diet. Effect on performance nutrient, digestibility, haematology- and Carcass characteristics," Journal of Fish Biology, vol. 10, pp. 481-491, 1997.

[53] I. Yamamoto, H. Kamimura, P. Yamamoto, S. Sakai, and M. Goda, "Effect of malathion on blood parameters of the fish, Cyprinion watsoni," Agricultural and Biological Chemistry, vol. 26, p. 709, 1962.

[54] "Handbook of toxicology: acute toxicities of solids, liquids and gases to laboratory animals," in Handbook of Biological Data, W. S. Spector, Ed., vol. 1, p. 408, W. S. Saunders, Philadelphia, Pa, USA, 3rd edition, 1956.

[55] M. T. Wan, R. G. Watts, M. B. Isman, and R. Strub, "Evaluation of the acute toxicity to juvenile pacific northwest salmon of azadirachtin, neem extract, and neem-based products," Bulletin of Environmental Contamination and Toxicology, vol. 56, no. 3, pp. 432-439, 1996. 

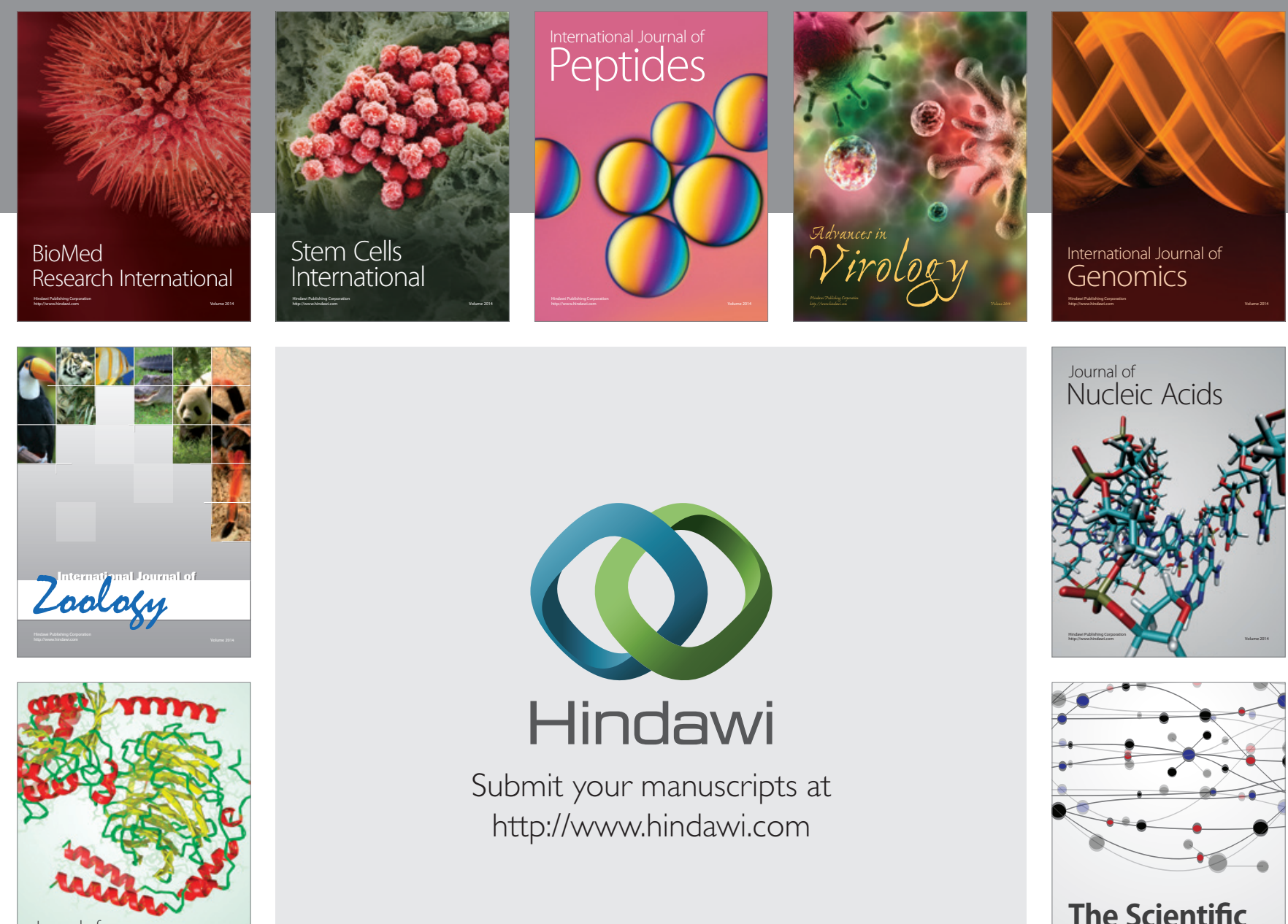

Submit your manuscripts at

http://www.hindawi.com

Journal of
Signal Transduction
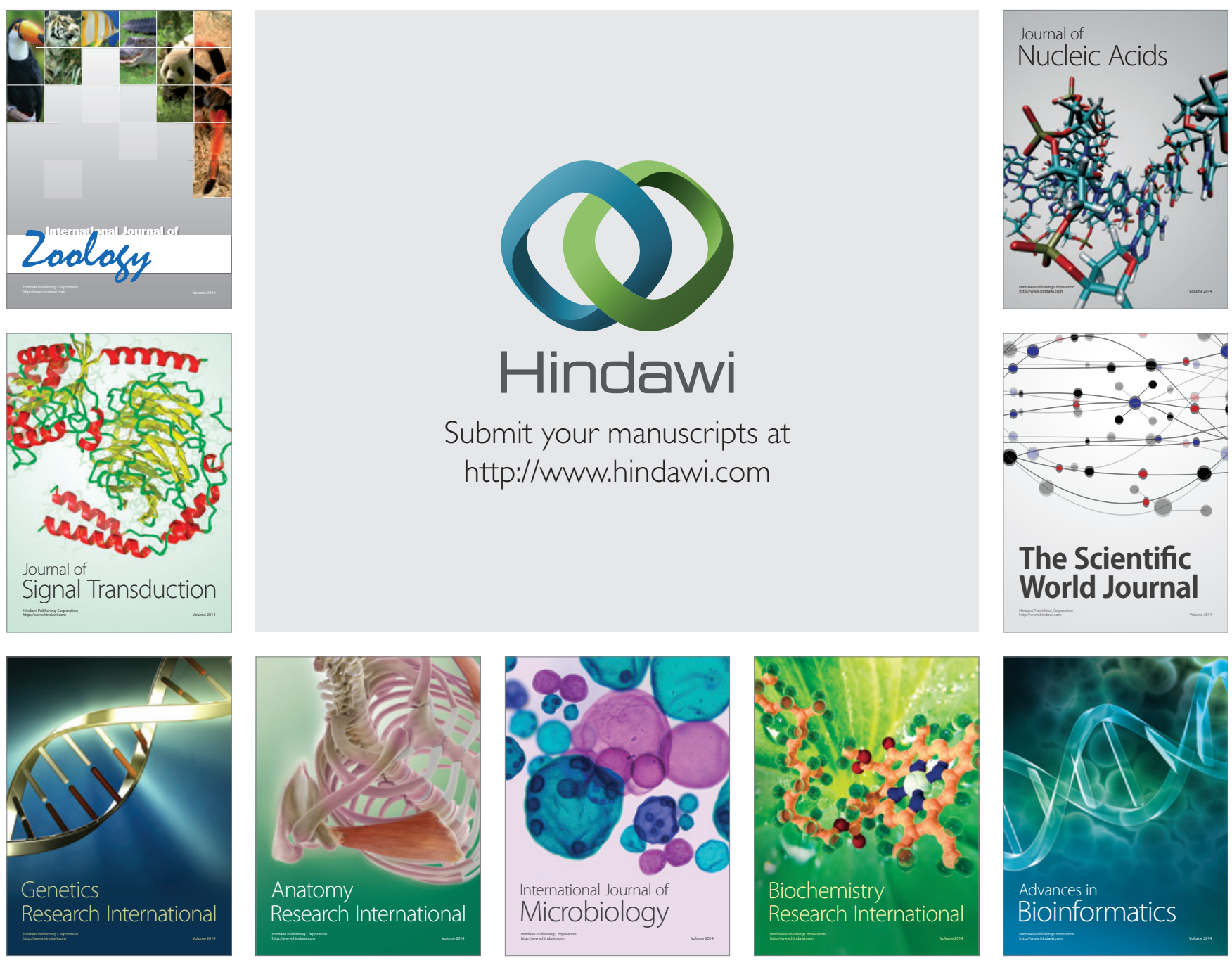

The Scientific World Journal
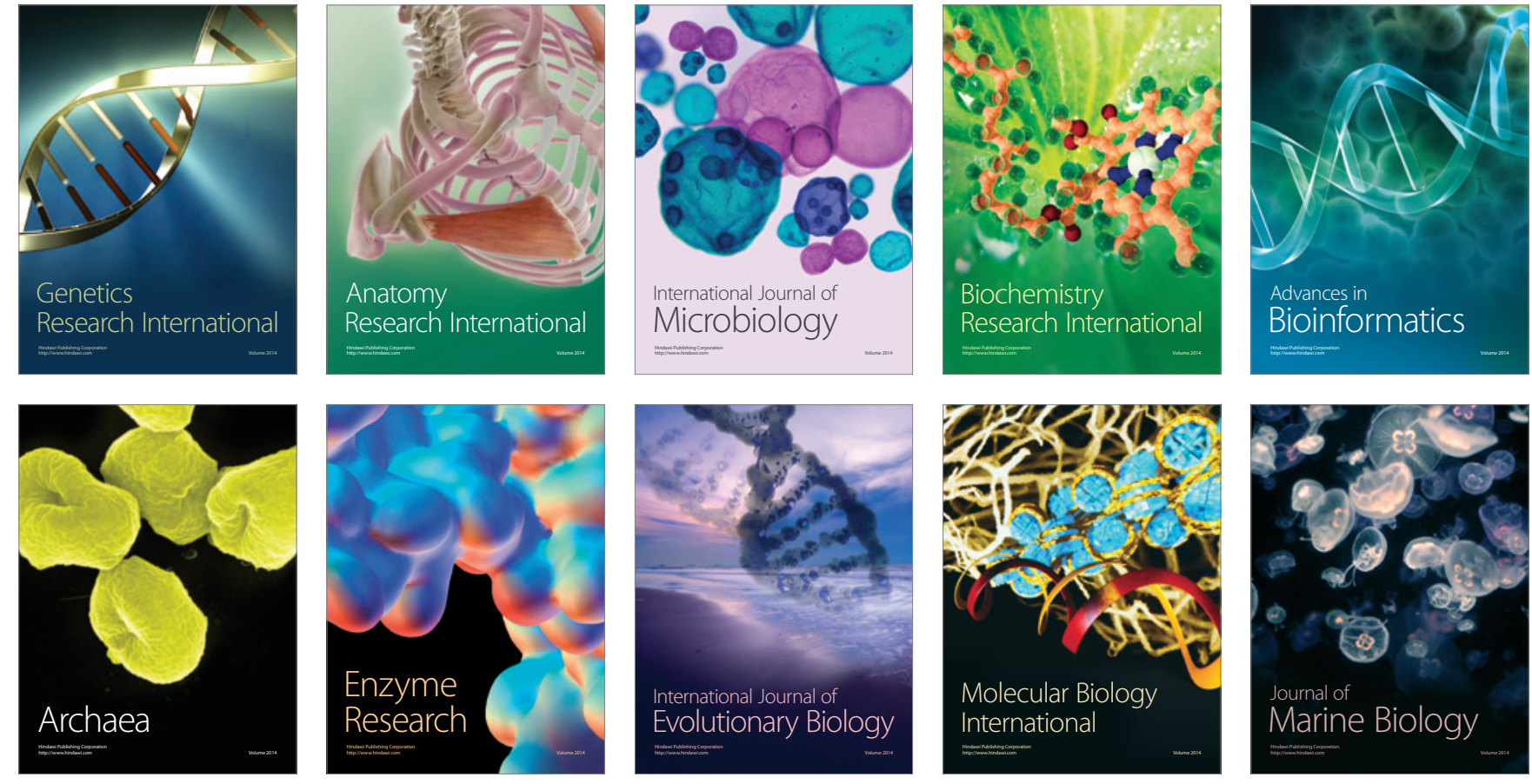